\title{
FIRST RECORD OF THE BOX TREE MOTH CYDALIMA PERSPECTALIS (WALKER, 1859) (LEPIDOPTERA, CRAMBIDAE) FROM KOSOVO
}

\author{
Donard Geci ${ }^{1}$ \& Halil Ibrahimi ${ }^{1, *}$
}

${ }^{1}$ Department of Biology, Faculty of Mathematics and Natural Sciences, Hasan Prishtina University of Prishtina, Mother Theresa Street p.n., 10000 Prishtina, Republic of Kosovo

Geci, D. \& Ibrahimi, H.: First record of the box tree moth Cydalima perspectalis (Walker, 1859) (Lepidoptera, Crambidae) from Kosovo. Nat. Croat. Vol. 27, No. 2, 343-345, 2018, Zagreb.

The box tree moth Cydalima perspectalis (Walker, 1859) is a native species of East Asia and it was accidentally introduced in Europe several years ago, most likely through the trade in live plants. It is spreading rapidly all over Europe, including the Balkans. In this contribution, we report for the first time this invasive alien species from Kosovo. A single specimen was found on August 20, 2017, in Veriq village, Istog Municipality. The specimen was observed on a light source nearby a decor plant, Buxus sempervirens $\mathrm{L}$., that offers favourable conditions for its spread.

Keywords: Box tree moth, Buxus, Kosovo, invasive species

Geci, D. \& Ibrahimi, H.: Prvi nalaz šimširovog moljca Cydalima perspectalis (Walker, 1859) (Lepidoptera, Crambidae) s Kosova. Nat. Croat. Vol. 27, No. 2, 343-345, 2018, Zagreb.

Šimširov moljac Cydalima perspectalis (Walker, 1859) je vrsta porijeklom iz istočne Azije koja je slučajno unesena u Europu prije nekoliko godina, najvjerojatnije putem trgovine biljkama. Širi se vrlo brzo cijelom Europom pa tako i Balkanom. U ovom radu donosimo prvi nalaz te invazivne strane vrste za Kosovo. Jedan primjerak je pronađen 20.8.2017. u selu Veriq, općina Istog. Primjerak je primjećen na izvoru svjetla nedaleko ukrasne biljke šimšira, koja pruža pogodne uvjete za širenje vrste.

Ključne riječi: šimširov moljac, Buxus, Kosovo, invasive species

The invasive moth Cydalima perspectalis (Walker, 1859) is naturally distributed in subtropical regions of China, Japan and Korea (e.g WALKen, 1859; Inoue et al., 1982). This species has up to three generations per year and overwinters in the caterpillar stage. It mainly feeds on the leaves of the genus Buxus, causing significant damage to the plants. In Europe C. perspectalis was first recorded during 2006 in Germany around the Baden-Württemberg area and soon spread to other parts of the European continent (e.g. Billen, 2007; Leuthard et al., 2010; Perny, 2010; Casteels et al., 2011; Sáfián \& Horváth, 2011; Griffo et al., 2012; Arnaudov \& RaIKov, 2017). One of the main ways of invasion is through the trade in ornamental plants and in particular in the genus Buxus, species of which are very popular garden plants.

In this contribution, we report the first record of C. perspectalis from Kosovo. A single adult specimen of $C$. perspectalis was found on August 20, 2017, in Veriq village of the Istog Municipality in the western part of the country. The specimen was observed on a light source near a Buxus sempervirens L. decor plant in a private backyard $\left(42^{\circ} 45^{\prime} 08^{\prime \prime} \mathrm{N}, 20^{\circ} 33^{\prime} 08^{\prime \prime} \mathrm{E}\right.$; Figs. 1 \& 2$)$. The species must have either been actively dispersed in Kosovo from neighbouring countries (Serbia or Montenegro) or it uninten-

*corresponding author: halil.ibrahimi@uni-pr.edu 
tionally transported through commercial imports of plants of the Buxus sp. infested with eggs or larvae.

The species is currently known from most of the Balkans and South-eastern European countries such as: Slovenia (SELJAK, 2012), Croatia (KoREn \& Črne, 2012; MAtošEvić 2013), Bosnia and Herzegovina (Ostojıć et al, 2015), Montenegro (Hrnčıć \& Radonjić, 2014), Serbia (Konjević et al., 2015), Greece (Strachinis et al., 2015), Romania (Szekely et al., 2011) and Bulgaria (Beshrov et al., 2015). Currently, the only countries in the area where this invasive species is not reported yet are Albania and Macedonia. It is still not known how widespread the species is in Kosovo, but considering that Buxus sempervirens L. is relatively present throughout Kosovo, we can conclude that the species has either invaded a large portion of the territory of Kosovo or will do so soon.

This invasive species causes severe damage across Europe to populations of the Buxus species, but sustainable control strategies are still lacking, mainly due to the fact that the ecological features and pest potential are still not totally understood in the invaded territories. The estimates of the potential damage in Kosovo are yet to be made and consequently adequate plant management should be taken into consideration.

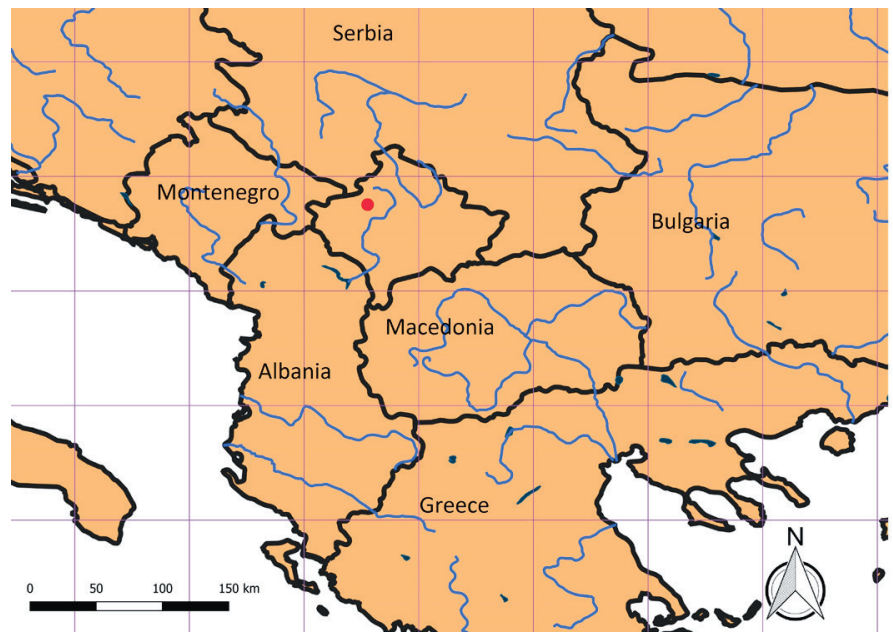

Fig. 1. The locality in Kosovo where Cydalima perspectalis was observed.

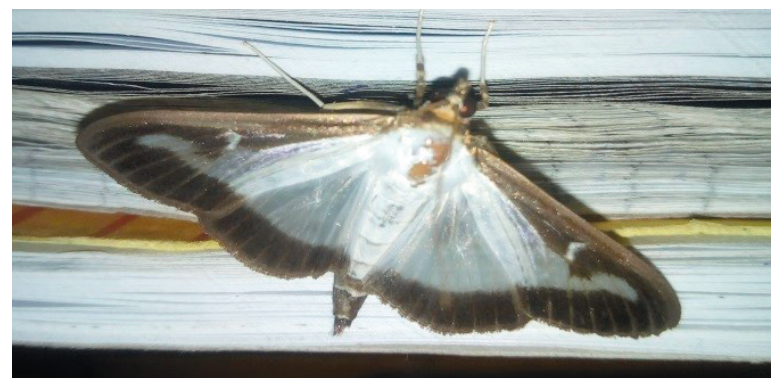

Fig. 2. The observed specimen of Cydalima perspectalis in Veriq village in Kosovo. (Photo by: D. Geci) 


\section{REFERENCES}

Beshkov, S., Aвadjiev,S. \& Dimitrov, D., 2015: Cydalima perspectalis (Walker, 1859) (Lepidoptera: Pyraloidea: Crambidae: Spilomelinae), New Invasive Pest Moth In Bulgaria. The entomologist's record and journal of variation 127, 18-22.

HRnčić, S. \& RAdonjIĆ, S., 2014: Cydalima perspectalis Walker (Lepidoptera: Crambidae) - nova invazivna štetočina šimšira u Crnoj Gori. Simpozij o zaštiti bilja u Bosni i Hercegovini, Teslić, 04. - 06.11.2014. godine, Zbornik rezimea. p. 24-25.

Inoue, H., 1982: Pyralidae. In: Moths of Japan 1, 2. Ed. by Inoue H., Sugi S., Kuroko, H., Moriuti, S. \& Kawabe, A. K., Tokyo, 307-404 (vol. 1), 223-254; 36-48, 228, 296-314 (vol. 2).

Koren, T. \& Črne, M., 2012: The First Record of The Box Tree Moth, Cydalima perspectalis (Walker, 1859) (Lepidoptera, Crambidae) In Croatia. Natura Croatica 21, 507-510.

KorycinsKA, A. \& Eyre, D., 2009: Box tree caterpillar, Diaphania perspectalis. FERA Plant pest fact-sheet. http://www.fera.defra.gov.uk/plants/plantHealth/pests [accessed 18.03.2018].

Leraut, P., 2012: Moths of Europe Zygaenids, Pyralids 1, Volume 3, Nap. Edtions. p. 600

Leuthardt, F. L. G., Billen, W. \& Baur, B., 2010: Ausbreitung des Buchsbaumzunslers Diaphania perspectalis (Lepidoptera, Pyralidae) in der Region Basel - eine für die Schweiz neue Schädlingsart. Entomo Helvetica 3, 51-57.

Matošević, D., 2013: Box Tree Moth (Cydalima perspectalis, Lepidoptera; Crambidae), New Invasive Insect Pest in Croatia. South-east European forestry 4(2), 89-94.

Ostojić, I., Zovko, M., Petrović, D. \& Elez, D., 2015: New records of box tree moth Cydalima perspectalis (Walker, 1859) in Bosnia and Herzegovina. Radovi Poljoprivrednog Fakulteta Univerziteta u Sarajevu (Works of the Faculty of Agriculture University of Sarajevo) 60 (65-1), 139-143.

SElJAK, G., 2012: Six new alien phytophagous insect species recorded in Slovenia in 2011. Acta Entomologica Slovenica 20(1), 31-44.

Strachinis, I., Kazilas, C., Karamaouna F., Papanikolaou N.E., Partsinevelos, G.K. \& Milonas, P.G., 2015: First record of Cydalima perspectalis (Walker, 1859) (Lepidoptera: Crambidae) in Greece. Hellenic Plant Protection Journal 8, 66-72.

SzéKely, L., Dincă, V. \& Mihai, C., 2011: Cydalima perspectalis (Walker, 1859), a new species for the Romanian fauna (Lepidoptera: Crambidae: Spilomelinae). Buletinul de Informare Entomologică 22, 3-4. 
